Tér és Társadalom 15. évf. 2001/2. 233-236. p.

Tér és Társadalom

XV. évf. 2001 — 2: 233-236

\title{
KÖNYVJELZÖ
}

\section{MÉSZÁROS REZSŐ: A TÁRSADALOMFÖLDRAJZ GONDOLATVILÁGA}

\author{
(Szegedi Tudományegyetem Gazdaság- és Társadalomföldrajzi \\ Tanszéke, Szeged, 2000. 164 o.) \\ SZÖRÉNYINÉ KUKORELLI IRÉN
}

Nagyon találó a könyv címe. Nem tankönyvet tart kezében az olvasó, hanem egy átfogó, a geográfia alapgondolatain és fogalmain attivelö összefoglaló elméleti gondolatkört, azt a gondolatkört, amely végre hiánypótlásként megjelent a magyar földrajzi és regionális tudomány szakkönyvtárában. Az elmúlt évtizedekben ahogyan Mészáros professzor is írja -, elsősorban az empirikus munkák sorakoztak. A földrajz, s annak talaján elinduló regionális tudomány a területfejlesztés gyakorlati oldalán ontotta a szakcikkeket, $s$ tankönyveket.

A könyv a földrajzi terminológiában használatos filozófiai fogalmak talajáról indul, $s$ úgy is mondhatnánk: rendet tesz. Erre a rendrakásra nagy szüksége volt a honi földrajztudománynak. A könyv az eddigi hazai hagyományos társadalomföldrajzi mü helyett egy alapozó, rendszerelméleti megközelítést ad, s kritikusan elemzi a hazai és nemzetközi társadalomföldrajz válságait, s elemzi a válságot kiváltó okokat és a súlypontok eltolódásait is.

„A földrajz tértudomány” - gyakran hangzik el a geográfusok szájából, mégis sok évtizedet kellett arra várni, hogy magyar nyelven is olvashassunk geográfus szemmel a tér filozófiai megközelítéséröl, a különbözö térfogalmakról és osztályozásukról. Mészáros professzor a természettudomány különbözö területén használatos tereket bemutatva közelít a földrajzi térhez, és megismerhetjük az olyan térfogalmakat is, mint a fraktális vagy a diszkrét terek, amelyeket a matematikából kölcsönözhetünk, majd a társadalmi-gazdasági tér és a kognitív tér bemutatását követően eljut a cyberspace-hez (virtuális tér). A cyberspace a 21 . század új térkategóriája, amely azt hivatott igazolni, hogy az új kommunikációs rendszerek használata egy virtuális teret képez, azaz az informatika eszközei, az információs rendszerek térformáló tényezóként foghatók fel.

A hely-tér-idö reláció fejezetben olvashatunk a könyvben a térszerkezet fogalmáról. Ez az a fogalom, amelyet különösen a kilencvenes évek kutatásai elöszeretettel használtak, bemutatva a térszerkezeti változásokat, viszont elméletileg nem járták körül magát a fogalmat. A könyv megteszi ezt. A hagerstrandi diffúziókutatás rövid áttekintése után a space-time geography (idö-tér földrajz), azaz az időföldrajz rövid összefoglalása és fogalmainak, mint a térfolyamat, térpálya definiálása következik. Erre a hiánypótlásra nagy szükség van a magyar szakirodalomban, $s$ tekinthető ez egyben felhívásként is azok felé a 
fiatalok felé, akik új kutatási területet keresnek. $\mathrm{Az}$ idő mint elérhetőségi hatótényezỏ a ma egyre inkább hangsúlyozott versenyképesség irányába hat, s a relativ tér jelentöségét emeli ki.

„A tér szerkezete" címü fejezetben a szerzö összefoglalja a legfontosabb telephelyelméleteket, ugyan új információt és exakt levezetéseket nem ad, de nem is ez a célja, hanem az, hogy a teret helyezze az értékelés középpontjába, és éppen ezért nem lesz tankönyvízủ a fejezet. Thünentöl Weberen, Löschön és Christalleren át eljut Friedmanig és Ruppertig, felkeltve az érdeklődést ez utóbbiak iránt, ami egyben azt is jelenti, hogy a magyar geográfia mindez ideig nem idézte súlyuknak megfelelően öket.

Külőnősen a földrajzosok körében a tér és a gazdaság szerkezetét nem szokták együtt vizsgálni az építészettel, a szerző egy példán, Docklands (East End London) stratégiai tervén keresztül mutat rá a tér revitalizációjára, a funkcionális változására, S rámutat a szerző, hogy a stratégiai tervek primer módon összekapcsolják a geográfiát és az építészetet, de szekunder módon hat a geográfiára is, hiszen hat a funkcióváltásra, megváltoztatja a térfolyamatokat. Véleményünk szerint ez a fejezet inkább csak egy illusztrációként kapcsolódik a könyv egészéhez, inkább csak a társadalomföldrajz egy lehetséges feladata fogalmazódik meg benne, s ezen a ponton, a stratégia készítésben kapcsolódik össze a geográfia az egyre jobban önálló diszciplínává váló regionális tudomány gyakorlati oldalával, a stratégia készítéssel.

A szerzőt mint eredendöen geográfust erősen foglalkoztatja a földrajz sorsa, ágazati differenciálódása. Mind a magyar, mind a külföldi példákat felsorakoztatva mutatja be az emberföldrajzból kiszakadó ágakat, a szociálgeográfia hazai és nemzetkőzi iskoláját, de bemutatja a társadalomföldrajzot mint az emberföldrajz leginkább önállósult ágát, s a nyolcvanas évek végétől kezdődő hazai megerősődését. Reálisan elemzi és az egyes nézeteken keresztül mutatja be a gazdaságföldrajz válságát külföldön és hazánkban egyaránt, melyet valamennyien átéltünk. A válság mélyưlését fokozó ,új gazdaságföldrajz” Krugman „találmánya”, melynek leggyengébb pontja, hogy a valóságos társadalmi-gazdasági tértől távol van, csupán a formális modellekre alapoz. Megismerhetjük a bemutatás szintjén azokat az iskolákat és jeles képviselöiket, akik az emberföldrajz területén, a szociálgeográfiában és a szociálökológiában alkották meg elméleteiket, és a társadalmi tér komplex funkcionális szerkezetét értelmezik.

$\mathrm{Az}$ emberföldrajz tudománytörténeti rendszerének bemutatásán keresztül betekintést nyerhetünk a földrajz olyan különböző irányzataiba, mint a politikai, a regionális, a humanisztikus, az alkalmazott, a feminista vagy a radikális földrajz. $\mathrm{Az}$ időföldrajzról és képviselőjének, Hagerstrandnak a munkásságáról részletes elemzést kapunk, nálunk alig van mủvelője ennek a földrajzi irányzatnak, pedig, ahogy a szerző is említi, gyakorlati alkalmazhatóságát jól mutatják a különbözö szolgáltatások térbeli elhelyezésének tervezéséről szóló svédországi példák.

Ebbe a fejezetbe helyezi, de mégis kitüntetỏ figyelmet szentel a regionális tudomány kialakulásának és a fóldrajzzal való összekapcsolódásának. A nagy 
kérdés az, hogy vajon a regionális tudománynak és a földrajznak milyen a kapcsolata, a társadalomföldrajzhoz vezetnek-e a gyökerei, vagy a neoklasszikus közgazdaságtan modelljeihez? Tekinthetô-e alapdiszciplínának a fóldrajztudomány? Mennyire gyakorlati és mennyire elméleti tudomány? A tudomány hazai képviselőinek állásfoglalása mellett szerényen húzódik meg a szerző véleménye, mely Enyedi véleményéhez áll legközelebb, miszerint a regionális tudomány egy „magyarázó, modellező transzdiszciplináris tudáskészlet”. Ugyanakkor Mészáros professzor, mikőzben elismeri, sőt egyetért az új tudományterület szúletésével, elbizonytalanodik - ahogy ö írja -,,nem látok meggyöző garanciát arra, hogy ha felépül a regionális tudomány eszme és fogalmi rendszere, akkor képes lesz-e egyenrangú társként felosztani magát a terulleti problematikát elemző tudományok kőzött? Félek, hogy csupán arra lesz hajlandó, hogy ezeket a tudományokat segédtudományává fogadja, rosszabb esetben felfalja." Ügy érzem, itt a földrajzos szólalt meg.

A két legérdekesebb és nemcsak a szakma számára érdekfeszítő olvasmány a globalizációról és a Föld eltartóképességérỏl szóló fejezet. A globalizáció tơbb megkőzelítése kőzul a szerző a geográfia szempontjából azt emeli ki, hogy milyen hatással van a térszerkezetre, mennyire változtatja meg azt, illetve kifejti, hogy az egész folyamat egy új térszerkezeti szemléletet követel. Mészáros professzor úgy fogalmaz, hogy a "globalizáció tehát nem egy folyamat, hanem folyamatok komplex rendszere...". Bemutatja a globalizációs elméletek három, időben is elkülönithető csoportját, az uzleti élet globalizációját, a tơbbi szektor globalizációját, s a harmadik csoport elméletei az eltérő fejlödést és a sokféleséget, a globalizáció és a lokalizáció kiegyensúlyozását hangsúlyozzák. Ez utóbbi jelentheti a globalizáció pozitiv oldalát, a helyi kőzösségek, a helyi identitás felerősődését és az autonómiák életre hivását.

A globalizáció előrehaladtával látni kell, hogy kulcskérdéssé vált a világgazdasági viszonyokhoz való alkalmazkodás. Egyrészt a globalizált világgazdasági folyamatok új térszerveződésekhez vezettek, mint például a városrendszerek kifejlődéséhez, miközben az állam szabályozó szerepe csökken. Mégis egyidejüleg a regionális politikák újragondolása és erősődése figyelhető meg, azaz arra a következtetésre jut a szerző, hogy a világgazdaság a regionális folyamatok és a globalizált világ folyamatai közőtt csiszolódik. Ebböl a gondolatsorból vonható le az a következtetés, miszerint a globalizált világ térszerkezetére ható tényezők vizsgálata - beleértve az idófơldrajz ezen ágát is - a társadalomföldrajz újabb lehetősége elö́tt nyit kaput.

Rendkívul élvezetes a Főld eltartóképességének modelljeit és a fenntarthatóság kővetelményeit bemutató fejezet, melyet a szerzö az ember és természet kölcsőnhatásába helyez. Bemutatja a legismertebb világmodelleket, s eljátszik azzal a gondolattal, hogy egy természeti vagy környezeti katasztrófa bekövetkezése esetén mi történik - ezen a ponton összekapcsolódik a globalizáció és az eltartóképesség, mert egy természeti katasztrófa a globalizált gazdaságban kialakult pénzügyi fugggőségek miatt a természeti és társadalmi problémák nem 
összeadódnának, hanem hatványozódnának. Felhívja a figyelmet a társadalmi, etnikai konfliktusokban rejlö veszélyekre, egyik oldalon a túlnépesedés problémájára, a másik oldalon a gyilkos vírusok okozta tömeges halálra, vagy éppen a teljes génállomány előálliftására. Azt a választ kapjuk, hogy a globális jólét a források gazdaságos kihasználásától és méltányosabb eloszlásától függhet. „Valamit tenni kell!” - s úgy fogalmaz: „a fenntartható fejlődés lehet az a Föld fejlődési technológia, amely időt adhat az emberiség számára ahhoz, hogy felépítsen egy új múködési rendủ világot”. A globalizáció, az eltartóképesség és a fenntarthatóság a 21. század nagy kérdéskörei lehetnek a geográfia számára.

Még a könyv két fejezetéről nem szóltunk, a térinformatika és a modellek szerepéröl. A szerző arra buzdít minden geográfust, hogy legalább alkalmazza a térinformatikát, mely akkor is fejlődni fog, ha a földrajzosok nem tudják magukévá tenni, s kifejti, hogy a térinformatika az a terület, amely magában hordozza a földrajztudomảny újbóli egyesülési reményét. A modellek, amelyek felderítő, leíró és magyarázó modellként osztályozhatók, többször megjelentek a társadalomföldrajz területén, a hetvenes, nyolcvanas években elöszeretettel alkalmazták a hazai kutatók a matematikai-statisztikai módszereket, de ez már akkor másfél évtizedes késést jelentett a külföldhöz képest. Napjainkra a modellezés szerepe csökkent a társadalomföldrajzban, és alkalmazása differenciálja azt.

A nagy ismeretanyagot bemutató és szintetizáló könyv sok kérdést nyitva hagy, talán azért is, hogy kedve legyen a szakembereknek elgondolkodni, az idézett szakirodalomban elmerülni az olvasónak, akár egy-egy részterületen is, megőrizve ezt a komplex szemléletet, mert csak így születhet ilyen gondolatébresztő mü.

Erénye a könyvnek, hogy a filozófiai megközelítés ellenére közérthető stílusú, világos megfogalmazásokat tartalmazó, de tömör mü.

Úgy vélem, az egyik fö célja a könyvnek, hogy felkeltse az érdeklödést a különbőzó elméletek, iskolák irảnt, és az idézett szerzők munkásságának mélyebb megismerése felé irányítsa az olvasót. 